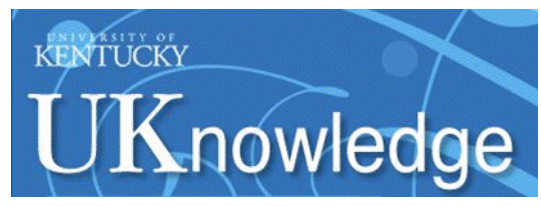

University of Kentucky

UKnowledge

August 1990

\title{
Blaming It on God: Considerations When Presented with Supernatural Explanatory Entities
}

James M. Donovan

james.donovan@uky.edu

Follow this and additional works at: https://uknowledge.uky.edu/law_facpub

Part of the Social and Behavioral Sciences Commons

Right click to open a feedback form in a new tab to let us know how this document benefits you.

\section{Repository Citation}

Donovan, James M., "Blaming It on God: Considerations When Presented with Supernatural Explanatory Entities" (1990). Law Faculty Scholarly Articles. 443.

https://uknowledge.uky.edu/law_facpub/443

This Article is brought to you for free and open access by the Law Faculty Publications at UKnowledge. It has been accepted for inclusion in Law Faculty Scholarly Articles by an authorized administrator of UKnowledge. For more information, please contact UKnowledge@lsv.uky.edu. 
Blaming It on God: Considerations When Presented with Supernatural Explanatory Entities

This article is available at UKnowledge: https://uknowledge.uky.edu/law_facpub/443 
In other instances, though, we may act with equal conviction, but for less valid reasons. What does the anthropologist do with statements that "god willed it" and "the spirits did it"? To dismiss them without good reasons is to be guilty of intellectual condecension; but what constitutes a "good reason," either to reject or to accept such testimony? This essay seeks to consider just such "good reasons," and see if they are as "good" as academic practitioners seem to assume.

BLAMING IT ON GOD: CONSIDERATIONS WHEN PRESENTED WITH SUPERNATUURAL EXPLANATORY ENTITIES

\section{JAMES M. DONOVAN}

\section{INTRODUCTION}

If the presence of an anthropologist at a fieldsite indicates that there exist unknowns, then for that anthropologist off-handedly to dismiss informant responses as being irrelevant, inadequate, or otherwise poor explanations for observed phenomena is an intellectually arrogant, if not dangerous, act (cf. Rosaldo 1989, 147). There are, of course, instances when this is a prudent reaction, but these decisions are usually dependent upon specifiable justifications. For instance, we can reject storks as an explanation for childbirth because we know enough about human reproduction and about omithology to render such an explanation unlikely in the extreme.

Copyright @ James M. Donovan 1991.
An informant's statements can be evaluated in terms of their adherence to standards of both truth and validity. "Truth," in this context, refers to the degree to which a statement faithfully reflects the informant's actual understanding of a set of circumstances. In optimal situations, most culture mates would agree with this assessment. Thus, the broad semantic scope of "truth" is here restricted to that which has as its polar opposite "lie." "Validity," on the other hand, here indicates the adequacy of a statement as a "real" or literally true explanation for the phenomena. We will be concerned here not with the ultimate validity of supernatural explanations, but rather whether they possess even prima facie validity. This distinction between true and valid roughly parallels the traditional anthropological dichotomy between emic and etic, respectively. Resemblances can also be seen with Tillich's (1987, 65) clarification of the difference between a symbol's having truth and its being true. ${ }^{2}$

If a statement is not true (i.e., is not believed by either the speaker or his/her culture mates), it can be valid only by accident. A statement that is true but not valid (e.g., storks) does not imply that the statement is meaningless. Statements can in fact be quite meaningful without being valid, as, for instance, Tillich's (1987. 147) assertion that "everything we say about being-itself . . . must be symbolic," and hence not literally true.

More pertinently, this is Freud's approach when he accepts claims that "God instituted the moral laws" as being true, not because there is a god in the literal sense, but because this is a valid, if poetic, way to express the unconscious processes which have generated the religious aspect. To Freud, God is the internalized (originally cannibalized) father, and moral law is 
synonymous with the perpetuation of resulting prohibitions against patricide and incest. All this he derives by taking seriously the surface content of informant explanation, without asserting it as being literally true (cf. Preuss 1987, 189).

Such analyses as these, however, can occur only after the worker has rejected the indigenous statement as being both true and valid. The task of this paper shall be to weigh the arguments both for and against this rejection of supernatural explanatory entities as valid.

\section{REJECTING THE SUPERNATURAL EXPLANATION}

The validity of a supernatural explanatory entity in the strong sense would entail knowing both that the entity exists and that that existing entity perpetrated the deed in question. Centuries of theological discussion have failed to prove the existence of the Christian god (cf. Tillich 1987, 187; Hick 1961, 209), and it would be unrealistic in the extreme to expect or demand better results with other conceptions of deity. However, the crux of the problem here is not whether gods and spirits are valid in any given case, but the prior issue of whether or not there exist sufficient grounds to treat them as legitimate hypotheses.

In practice, researchers behave as though they have good reason to overlook supernaturals as they construct naturalistic alternatives. For instance, I. M. Lewis (1989) argues that the membership of ecstatic possession-trance cults is characterized by socioeconomic variables indicative of marginalized groups, and goes on to explain this pattem via political disenfranchisement. Through the cult, subordinates are given a sanctioned context in which to voice their frustration to their hierarchical superiors. While the observed relationship may be factually true, Lewis' conclusions can function as an explanation for the pattern of cult membership only if that offered by the participants-that membership is motivated by actions by the spirits-is taken to be false. While theoretically either model could generate the observed pattern, only one is necessary. One must use criteria external to both theories to choose between them; or at least to rank them in order of importance to the question.

What should be a choice between alternative explanations, to be determined by research, is resolved instead by a de facto renunciation of the relevance of the supernatural competitor (cf. Firh 1959, 136). "Theoretical agnosticism" implemented with a "methodological atheism" (Berger 1967) permits scientists to reject the supernatural without requiring them to examine self-consciously why they do so. Yet anthropologists have an obligation to treat other cultures sensitively, and, as Flew $(1984,4)$ has reminded us, "surely, the truest way of showing respect for some conviction which you do not share is to pay it the compliment of an argued rejection."

Most social scientists would not admit that they "reject," along with their negative connotations, supernatural explanations. Instead, they would argue that it is beyond the scope of science even to consider such statements (e.g., Radcliffe-Brown 1952, 153; Geertz 1973, 112, 123). ${ }^{3}$ This professed disjunction between religion and science is itself a complex issue, and one beyond the immediate focus of this essay. But the justification of this perspective usually grounds itself in the inability of scientific methods to inform religious propositions. Assertion of these propositions as true therefore leave the realm of knowledge and enter into that of belief and/or faith. The common stance is that the first is the province of science, and the second of religion, with a wide chasm separating the two.

Social scientists behave as though they are justified in extending this conclusion into other cultural contexts. Yet, as we shall see below, many justifications to reject supernatural explanatory entities are unreflective in that they rely on ethnocentricisms.

\section{A. THE LACK OF EXPERIENTIAL TIES}

God as an explanation is only feasible if God's existence makes a difference in the material world. ${ }^{4}$ If severed from any 
relationship to the experiencial aspect of living, statements about God lack any truth-value (Schoen 1985, 5). "Just what," Flew (1984, 165) asks, "would have to happen, or not happen, or to have happened, to entitle us to say that ... "There is no God'?" (cf. Popper's [1980] criterion of falsifiability for a hypothesis to be scientific). If the answer is, "Nothing," then the claim that God exists is neither true nor false. From the scientists' perspective, then, it can be safely ignored, seeing that such entities have no relationship or discernable impact on the empirical world being studied.

At first glance, this seems an insurmountable objection to the consideration of supernatural explanations. But on closer inspection the major difficulty is less one of absolute standards than of perspective. Flew's question can be reduced to a legitimate research question if the advocates of the supematural explanation admit the possibility of conditions which would serve, if not to disprove the existence of gods, at least to argue strongly against their explanatory relevance. Presence of these circumstances would weaken the force of the supernatural hypothesis in this setuing.

The principal reason Flew's challenge seems so compelling is that it can be read with the presuppositions of a Judeo-Christian context, imagining God to be of a particular sort. Since God's will is argued to be inscrutible, there is no evidence which can be held against God. But other religious systems are more demanding of their deities.

"If a deity cannot say something specific," says one cult follower, "why should we come to that deity?" (Harper 1957, 278). Similarly, Crapanzano $(1980,75)$ says that the existence of Moroccan saints and jinniyja is "confirmed through action." Explicit demands are made of gods, for which the supplicants promise due obeisance. Failure of the gods to fulfill their promises will frequently cause the believer to surrender allegiance to this entity, and perhaps switch to another who is hoped to be more effective.

As an example, Segato $(1984,623)$ recounts the following incident in the life history of a Candomble paricipant: "After everything was stolen from her home on the very day an offering had been given [to her saint], her fostermother renegated from the saint and threw away all the ritual paraphemalia of her saints into the river which ran at the back of their house." What might be interpreted as a "mystery" within the Judeo-Christian system-a loving and paternal God who yet tolerates the presence of evil-is here construed as counterevidence to a second system, at least by some practitioners.

Flew's challenge, I think, can be met in environments such as this since in these systems a spirit's existence is less than interesting if there is no obviously active power atuached. In other words, "miracles" can be a standard expectation of some religions, the absence of which negatively impacts upon the allegiance of their members; Christians, by contrast, may be seriousiy disappointed by the lack of a miracle, but since their god is under no obligation to perform, their lack does not inform one way or the other about their god's existence.

If divine intervention is in practice synonymous with divine existence, and if this intervention is characterized by the system as at least an implicit obligation of the entity, either because the gods "love" their followers or, and more likely, because this intervention is half of a reciprical and contractual relationship, then adherents to the religion should be able to imagine patterns of events which would distinguish between the absence or presence of the active supernatural. If this distinction can be made, then Flew's challenge is a research problem to be settled on the evidence, and not a warrant to ignore at the outset the possible validity of supernaturals as explanatory entities.

\section{B. GOD AS OMNIPOTENT AND UNIQUE}

The assumption that Flew's challenge presented a universal conundrum arose, as we saw, from an overextension of conclusions legitimate within the Christian context into others with different premises. This mistake is not uncommon. A second 
support for a priori dismissal of supernatural hypotheses also rests upon similar ethnocentricisms.

Besides being thought to be unrelated to the real world, supernatural explanations are held by some to be irrelevant to scientific inquiry because they are too powerful. What could not be explained by the will of God? And, as we know, that which explains everything explains nothing. So here, with the uselessness of the God-hypothesis plainly revealed, scientists feel absolved of any responsibility to consider it seriously. They might consider the following. First, objections to the God-hypothesis, especially as articulated by Hospers (1980), are predicated not on the necessary attributes of supernatural entities per se, but, again, on those peculiar to the Judeo-Christian god. An omnipotent. omnipresent, inaccessible deity may in fact be a poor explanatory entity; but what of a god that is less than all-powerful?

One Indian deity, for example, admits that he has limits, that he cannot cure all illnesses, and that spirits do not know everything, even all the other spiritş (Harper 1957). These limitations may exempt this supernatural entity from the scope of the rejected God-hypothesis.

This possibility leads us to consider another aturibute predicated of the Christian god, namely, that this god is unique. Even if God as the Supreme Being is 100 powerful to be used as an explanatory entity, this does not rule out the use of other supernaturals unless one also presupposes that there are none. Religious systems with a plurality of supernatural entities are often headed by a high god similar in autributes to the Christian one. Exclusion of this supreme god does not automatically preclude the use of a lesser one as an explanatory entity.

Some. Christian theologians attempt to get around this problem by arguing that the existence of the supreme deity necessarily entails the impossibility of the existence of lesser deities. Such argumentation is seriously flawed, however. Dore $(1983,152)$, for instance, holds that the

concept of God is such that it is a necessary truth that if God exists, then God is a radically unique being, in the sense that it is logically impossible for any other being even to come close to rivalling him with respect to the degree and number of his perfections. . . . But the concept of a minor deity is such that it is a necessary truth that if minor deities exist, then they rival God with respect to the number of their perfections. It follows that, given that God exists, minor deities are logically impossible.

That God is to be unrivalled "with respect to the degree and number of his perfections" is of course a matter of a particular theological definition, and not an inescapable consequence of the idea of the supernatural. Nor is belief in the nonexistence of other deities an inherent feature of even Christianity (Barth 1961). But exactly how many "perfections" an entity must have to "rival God" is left unspecified. It may be stated that even one perfection places a candidate well above mere humans without seriously rivalling God, whose perfections are alleged to be infinite. Therefore, this argument does not exclude an intermediary class of entities between humans and God, at best only demonstrating that they are probably closer to humans than to God. $^{7}$

These arguments, however well they may succeed in denying the relevance of the Christian god in a scientific investigation, fail to provide even a modicum of assurance that these conclusions can be carried over by the anthropologist into other religious systems as a given. To my knowledge, there exists no argument that will, without at least some thoughtful modifications, legitimately permit an a priori rejection of an informant-offered supernatural explanation. Each case must be considered on its merits until such time as a universal proof is generated. Failure to provide an adequate justification for the rejection of the supernatural hypothesis in that context must necessarily weaken the credibility of the naturalistic explantion offered in its stead.

\section{ACCEPTING A SUPERNATURAL EXPLANATION}

If there are no grounds for universal and a priori rejection of supematural explanations, this result in itself provides no justification for the opposite approach, namely, the positive 
assumption that supernaturals are valid unless evidence points against it.

Some writers would hold that supernatural explanations can win more or less by default if "the proposed religious explanation solves a problem that is neither solved more adequately by some alternative account nor even on the agenda for solution by any other, more acceptable research tradition" (Schoen 1985, 177). But, as Johnson $(1981,19)$ argues, an

explanation is not shown to be correct merely because it is adequate. Nor is it shown to be correct because it is the only adequate explanation we have yet developed. An explanation is shown to be correct when experiments designed to disconfirm it fail.

The issue of testing supernatural claims is legitimate and interesting, but is also beyond the focus of this paper because a test is warranted only if the hypothesis is first judged to be at least valid on its face, so that, if verified, the phenomenon can be deemed explained.

What are the situations when a supernatural hypothesis can be considered adequate, that is, possessing no obvious flaws or shortcomings that must disqualify it at the outset? When can the anthropologist accept a particular claim of supernatural causation to be sufficiently reasonable to justify the time and expense required to test it for ultimate validity?

\section{A. RELIGIOUS PLURALITY}

Let us assume in this section that spirits do exist as a category of reality. Even in this generous theoretical environment, wherein the literal existence of supematural entities is given, there still exists no warrant to presume that all presented deities are real. Quite the contrary.

Several religious belief systems explicitly exclude the possibility of any other system sharing its claim to veracity. Prominent among these would be some forms of salvation religions such as Christianity, Islam, or Judaism, which assert that they alone know the "way" or hold the "key" to everlasting life. All those who lack this knowledge or membership are outsiders to suffer the penalties of eternal exclusion from the chosen community. Conflicting claims can also arise between denominations of a single religion, as between Protestants and Catholics."

Our alternatives seem to be these: First, we can claim with Cicero that

in this medley of conflicting opinions, one thing is certain. Though it is possible that [the religions] are all of thern false, it is impossible that more than one of them is true. (quoted by Preuss 1987, 10; cf. Carmichael 1949, 53)

Not all religious systems make exclusive claims of truth. But when considering one that does, the anthropologist should have grounds for accepting any particular system, given that to accept one of these as literally true implies that the other, systems claiming exclusivity are false."

A second alternative is that while all these religious expressions point to real interaction with supernaturals, claims for exclusive truth are so much squabbling, rather like the claims by various countries to have found the best possible lifestyle. In this scenario, however, the gods who have exaggerated their epistemological status lose some other of their attributes. The high god becomes a deceiver, one who is not above stretching the truth while jockeying for position among fellow gods in the spirit realm. While this is a logical possibility, it renders the reality of deities bootless: Since they will have misled on this issue, it would be difficult to accept as valid any other claim based on revelation, including that they caused something.

It is not, of course, possible to resolve these questions here. Suffice it to say that the conflicting claims of exclusivity of some religious systems compel even the most uncritical of acceptors to doubt either the existence of some claimed deities, or whether these deities exist in the rank and power claimed. Conceding the abstract class of supernaturals as a given, then, helps but little because the fieldworker must still present grounds for accepting a 
particular conception of deity as real, and hence adequate for use as explanatory entities.

\section{B. ESTABLISHING INFORMANT CREDIBILITY}

Flew, in his introduction to Hume (1985), tells us that

Hume's prime concern here is with knowledge, and hence with evidence rather than fact. He is not asking whether any miracles have occurred or do occur. . . . Instead he is asking whether and, if so, how-even supposing that a miracle had occurred-we could know, repeat know that it had. (p. 4)

In a separate work, he clarifies just what is entailed by knowing:

For to know, in the ordinary and more exacting sense, it is not enough metely to feel absolutely certain and to act accordingly. It is necessary also for your belief to be in fact right, and for you to have sufficient reason to warrant your confidence. ... The man who 'knows' but who 'knows' wrong, or the woman who 'lonows' but is unable to produce any grounds for her conviction. does not, in this ordinarily exacting sense, know at all. . . . (Flew 1984, 8)

These statements capture perhaps the single biggest obstacle to the framing of a supernatural hypothesis. Granting not only that spirits exist as an abstract category, but also that the informant has interacted directly with such, how can this knowledge be communicated, if at all, to the anthropologist?

Before a fieldworker can entertain a supernatural explanation, he or she must have reason to conclude that the informants are in a position to know, in Flew's sense, that the deity perpetrated the deed in question. Mere group consensus is not sufficient to establish this credibility, for then the informant may be reliably reporting group perception, but not necessarily the actual circumstances (cf. Romney et al. 1968).

Optimal circumstances credentialing informant accuracy are when statements are made first-hand. This requires some direct interaction with the alleged deity. In other sitwations this would not be a terribly difficult criterion to meet. But knowledge of God is unique: "mystical knowledge is not new knowledge of any facts of doctrines, but rather the perception of an overall meaning in the world" (Weber 1963, 169). This experience of perception preceeds the interpretation of that experience, where it assumes linguistic forms. But, since "reports do not entail ... that there is something answering to the mystic's interpretation of his "experience"" (Nakhnikan 1961, 163), establishing informant credibility entails certifying that verbal statements are correct conclusions drawn from the experience (cf. Crapanzano 1980, 21). This requires access to the experiential "raw data," and not merely the derived expressions.

From at least Plato onward, however, this experience has been held to be incommunicable (Roszak 1980, 309). It is possible only to talk about and around it; in fact, Maslow $(1976,24)$ claims that the ritual apparatus of organized religions is an attempt to communicate (largely unsuccessfully) the "original mystical experience of the original prophets."

If it is difficult for the informant to encode the necessary information to be conveyed for communication to the anthropologist, worse still are the assertions that successful decoding can be done only by those "who already know what you mean" (Maslow 1976, 84; cf. Murphy 1988, 128). As Freud $(1961,28)$ objects:

If the truth of religious doctrines is dependent on an inner experience which bears witness to that truth, what is one to do about the many people who do not have this rare experience? ... If one man has gained an unshakable conviction of the true reality of religious doctrines from a state of ecstasy which has deeply moved him, of what significance is that to others?

A third problem is the goal of religious discourse. Sometimes it is "aimed at inspiration, not information" (Barrett 1988, 79), where to "understand a religious expression supposes that a passion will ... follow the leaming" (Holmer 1961, 47). The anthropologist, then, cannot assume that the offered supernatural explanation is intended as a simple declarative statement. The 
motivations of the informant must therefore be assessed prior to a determination to accept the supernatural claim. Critical here is whether the reply is answering the question "Why" by identifying the cause for, or by atuributing a meaning to, the phenomena. While the anthropologist can perhaps receive knowledge of the supematural directly by submiting to the pivotal experiences (cf. Luhrmann 1989), this does not resolve the problem. It is an accepted canon of scientific methodology that the final step in a research program is to disseminate the results (Szasz 1974, 112). So while the anthropologist has settled the matter of the informant's credibility in his or her own mind, there yet remains the matter of the anthropologist's credibility when writing up the data. Without general access to (someone's) raw data at some point, the problem of credibility is merely passed down the line.

\section{CONCLUSIONS}

While in the field recently, I had the opportunity to interview spirits incorporated in various mediums. The first difficulty in interpreting these data is knowing to whom the statements should be attributed. If interviewing a spirit is assumed to be synonymous with interviewing the medium-although if you allow the legitimacy of the trance then you might say you are accessing a "deeper" level of consciousness-then psychological theories are appropriate to interpret the variation in statements between states of consciouness, and perbaps sociological and cultural theories to account for general patterns. The appropriate tools for analysis, and certainly the questions to be asked of the data, would be dramatically different if statements from the spirit were to be attributed to an agent independent of the medium.

The difficulty is deciding between these mutually exclusive alternatives. As this essay tried to show, I am aware of no rationale which would justify the universal acceptance or rejection of supematural explanations. In other words, I cannot look to earlier work, theological or scientific, and expect to find a solution to this problem. Anthropologists should therefore he neither so cynical that they enter the field prepared to disregard (and thereby discredit) all such explanations, nor so gullible that they believe them all. Both options require a case-by-case determination on the merits, and however the fieldworker decides to treat the data, he or she should be able to articulate exactly how he or she arrived at this conclusion.

Most of the conventional supports for rejection have depended upon a narrow, ethnocentric conception of divinity which does not always apply cross-culturally. Those who wish to preserve the current Western research tradition intact and categorically reject supernaturalisms must devise new proofs which attack the possibility of supernatural entities without predicating to them any particular atuributes. The more open-minded, who adhere to a standard of falsifiability, may find a way to demonstrate an alleged spirit's lack of empirical effectiveness so that he or she can logically exclude the validity of a supernatural explanation; this should be a more manageable task than trying to prove existence.

Failing to accomplish either of these tasks, the anthropologist should not obsure the indeterminate nature of the question. Instead, he or she might consider showing how the two explanations might be compatible. Hick $(1961,207)$ claims that the concept of god can have its roots in the human psyche without necessarily challenging a religious interpretation that god "made him this way." Referring back to the example of Lewis" (1989) sociological interpretation of membership in possession-trance cults, if we cannot decisively exclude the supernatural explanation. a testable combination is conceivable. Socioeconomic variables and the like may serve as proximate explanations, while spirit preference for persons with certain values of these variables fumishes the ultimate explanation. Given the accessibility of these entities, one could gather data on why a spirit chose its particular medium. ${ }^{10}$

While these are difficult and challenging lasks, I suspect they will be more easily achieved than those confronting the literal acceptors of supematuralisms. They must establish both the certification and credibility of a particular claim. The first requires some set of criteria by which false or exaggerated systems 
can be winnowed from the true or accurate; the second needs access to the experiences which warrant the informants' conclusion of supernatural causation.

There is no room here to consider the probable directions and outcomes of these research programs. My goal here has been to outline the types of data which are presently lacking but which are necessary before the materialist, for example, can legitimately dismiss the supernatural as an effective agent in the shaping of social patterns, or before New Age channellers are accepted as a literally tue phenomena.

\section{$M$ \\ James $\%$ Donovan \\ Department of Anthropology \\ Tulane University}

\section{NOTES}

1. Informans have been bnown to lie to the visiting anthropologist. For instance. informanks withbeld a target language and led foreigners to believe that the pidgin they were leaming was in fact the real language (Thomasco and Kaufman 1988, 174-176); Stoller and O1kes $(1987,8-11)$ repon how 180 Songhay informents lied during one month of interviews; and, for a case where the anthropologist failed to detect the deception, Freemen (1989) daims that Margaret Mead's adolescent informants deliberately lied to her.

2. This distinction is not self-evident, and its recognition apparently requires culbural elaboration. While Wertem culture admits a pocential incongruity between the appearance of something - and descriptions of that appearance-and that thing's actual sure, the assumed independence of the two is noe salient. Greenfield (1969. 219) repons that

unzchooled Wolof children... do no distinguish between their own thought or a statemem about something and the thing itself. Thought and the object of thought seem so be one. Consequently, the iden of explaining a statement is meaningless; it is the extemal event that is to be explained.

Thus, while we may recognize the possibility that a statement can be descriptively true yet still be invalid, such distinctions in the types of knowledge should not be assumed to be "natural."
3. Discussion on the issue at all is relatively rare. Flew (1984, ix), among others, observes that discussion of the subject of the validity of supematural explanatory entities is "widely discrediled." This depiction is in fact probably more accurnte. It may not be a case where social scientists think the issue has been resolved, albeit perhaps erroneously, but rather that it is not for most a legitimate question in the first place.

4. The emphasis of this paper is the contrast between supernatural in the sense of immaterial, and naturalistic explanations. Therefore, no distinction is made between the varieties of supernatural entities. "God," "spirit," "deity," etc., are used interchangeably unless explicitly anced otherwise.

5. As a methodological note, anyone endeavoring to make this comparison between religious expectations and empirical ouccomes should be mindful to keep the input consistent. Ideally, expectations should be of individuals for personal outcomes. To the extent that cultures have religions at all, this information is extrapoluted from raw dain aggragated from individuals. Thus, the cultural syatem is a heuristic "nverage" often created by the anthropologist and not in fact espoused by any particular culture participant. It would be inappropriate, then, for this averaged description of the religion to be the standard by which predictive outcomes indicative of supernatural intervention in any specific and personal instunce are generated.

6. Same theologims would hold that even the Christian god is nol omripotent in the popular sense of being able to do literally anything it choses to. Thus, Flint and Freddoso (1983) can specify actions which, being necessarily unacuutizable. such as changing the past, are beyond the power of even a genuinely omnipotent deity without anch limitations detracting from its status. Even these restrictions, however, leave the Christian god considerably much more powerful than some other deities.

7. Elsewhere in the same volume, Pike (1983), in his discussion of "overpower," unwittingly provides en excellent illustration of how ethnocentric assumptions blind workers to aliernative interpretations. His Figure 4 shows a diagram whose circuit is completed by closing either A1 alone, or A2 and B. Reading A and B as Arthur and Bailey respectively, Pike says that though "boch Arthur and Bailey have power sufficienx to determine the condition of the ligh. Arthur has power sufficient to decermine which, if any, powers Bailey shall have at any given moment." Yea the diagram does not require that the gates labeled $A 1$ and $A 2$ be opented by the same entity. What Pike uses to illustrate his theory could just as ensily, if not more so. be a model for polytheism, where A1 is the supreme god and A2 corresponds to at least one minor deity. Thus, the supreme god potentially cen control all events. but has the option of delegating reponsibilities to both human and other sopematural actors.

8. Assumed herein is that the tuuted exclusivity is revealed knowledge by the gods themselves, and not extrapolation by the faithful.

9. Hume $(1985,40)$ suggests that in fact no religion can contradict the claims of another without simultaneously undermining its own grounds for revelation: 
Every mirscle... pretended to hove been wrought in my of these. religions, .... as is direct scope is to exreblish the particular system to which it is altributed; so has it the same force, though more indirealy, to oventhrow every other system. In destroying a rival system, it likewise destroys the credit of those miracles, on which that system was extablished.

If mincles, in other words, do not validate the clains of rival religions, then likewise miracles cannot be used to validate the claims of the favored one. And since all religions are founded on miracles of one sort or another, then either all religions are validated by the presence of miractes, or none are.

10. A second altemative not considered bere may be al leas mentioned. The studeat may accept as literally true the atrunge phencenena reported by informants while rejecting the interpretutions of these events as being caused by spirits. This upprouch would require the developinene of some theory or theories which could scocunt for the events without the introduction of immaterial agents. An obvious candidate would be theories from the field of "parnpsychology."

\section{REFERENCES}

Barret, Leonard E. 1988 The Rastafarians: Sounds of Cultural Dissonance (rev. ed.). Boaton: Beacon Press.

\section{Barth, Markus}

1961 "On God's Existence," in Sidney Hood (ed.), Religious Experience and Truth: A Symposium, New York: New York University Press, 220-223.

Berger, Peter L.

1967 The Sacred Canopy: Elements of a Sociological Theory of Religion. Garden City: Doubleday and Company.

Carmichuel, Peier A.

1949 "Limits of Religious Knowledge," in Philosophy and Phenomenological Research 10, 53-64.

Crapanzano, Vincent

1980 Twhami: Portrail of a Moroccan. Chicago: Univerviky of Chicago Press.

Dore, Clement

1983 "Descarte's Meditution V Proof of God's Existence," in Alfred J. Freddoso (ed.). The Existence \& Nature of God, Notre Dame, Indiena: University of Norre Dame Press, 143-160.

Finh, Raymond

1959 "Problem and Assumption in an Anthropological Sudy of Religion," in Jownal of the Royal Anthropological Institwe of Great Britain and Ireland 89(2). 129-148.
Flew, Anthony

1984 God: A Critical Enquiry. LeSalle, Illinois: Open Count Publishing Col. [Revised edition of God and Philosophy, 1966).

Flint, Thomas P., and Alfred J. Freddoso

1983 "Maximal Power," in Alfred J. Freddoso (ed.), The Existence and Noture of God. Notre Dame, Illinois: University of Notre Dame Press, 81-113.

Freeman, Derek

1989 "Fa'apun's Fa'amu and Margarel Mead," in American Anthropologist 91(4), 1017-1022

Freud, Sigmund

1961 The Future of an Illusioin. Trans. James Sirachey. New Yoik: Norton.

Geentz, Clifford

1973 The Inderpretation of Cultures. New York: Basic Books.

Greenfield, P. Marks

1969 "On Culure and Conservation," in D. R. Price-Williams (ed.), CrossCulfural Studies, Harmondsworth: Penguin Books, 211-245.

Harper, Edward B.

1957 "Shamanism in South India," in Sowthwestern Jownal of Anthropology 13(3), $267-287$.

Hick, John

1961 "Meaning and Truth in Theology," in Sidney Hook (ed.), Religiows Experience and Truth: A Sympositum, New York: New York Univervity Press, 203-210.

Holner, Paul L.

1961 "Scientific Language and the Languige of Religion," in Jownal for the Scientific Study of Religion 1(1), 42-55.

Hospers, John

1980 "What is Explanation?" in E. D. KJemke, Roben Hollinger, and A. David Kline (eds.), Intraductory Readings in the Philosophy of Science, Buffalo: Prometheus Books, 87-103.

Hume, David

1985 Of Miracles. Ed. Anthony Flew. LaSalle, Iltinois: Open Coun Publishing Co.

Johnson, B. C.

1981 The Alheiss Debater's Handbook. New York: Prometheus Books.

Lewis, 1. M.

1989 Eestatic Religion: A Study of Shamanism and Spiri Passession (2nd edition). London: Routledge.

Luhmann, T. M.

1989 "The Magic of Secrecy," in Echos 17(2), 131-165.

Maslow, Abraham H.

1976 Religion. Values, and Peak Experiences. Hamondsworth: Penguin Books. 
Mumphy, Joseph M.

1988 Santeria: An Afican Religion in America. Boston: Beacon Press.

Nakthikion, George

1961 "On the Cognitive Impont of Certuin Conscious States," in Sidney Hood

(ed.), Religious Experience and Truth: A Symposiwn, New York: New York University Press, 156-164.

Pike, Nelson

1983 "Over-power and God's Responsibility for Sin," in Alfred J. Freddoso (ed.). The Existence and Notwre of God Notre Dame, Indiens: University of Notre Dame Press, 11-35.

Popper, Kerl

1980 "Science: Conjectures and Refutations," in E. D. Klemke, Roben Hollinger, and A. David Kline (eds.), Intraductory Readings in the Philosophy of Science, Buffalo: Prometheus Books, 19-34.

Preuss, J. Samuel .

1987 Explaining Religion: Criticism and Theory from Badin to Frewd. New Haven: Yale University Press.

Redcliffe-Brown, A. R.

1952 Structure and Function in Primitive Society. New York: Froe Press.

Romney, A. Kimball, Susan C. Weller, and Willian H. Batchelder.

1986 "Culture as Consensus: A Theory of Culture and Informant Accuracy." in American Anshropologist 88(2), 313-338.

Rozaldo, Rensato

1989 Culture and Truth: The Remaking of Social Analysis. Boston: Beacon Press.

Roszak, Theodore

1980 "The Monster and the Titan: Science, Knowledge and Gnosis," in E D.

Klenke, Roben Hollinger, and A. David Kline (eds.), Introductory Readings in the Philasophy of Science, Buffalo: Prometheus Books, 305-322.

Schoen, Edwand L.

1985 Religious Explanations: A Model from the Sciences. Durham: Duke University Press.

Segato, Rita Laura

1984 Folk Theory of Personality Types. Unpublished Ph.D. disseration, Queen's University. Belfast.

Stoller, Peul, and Cheryl Olkes 1987 In Sorcery's Shadow. Chicago: University of Chicago Press.

Szasz, Thomas S.

1974 The Myth of Mental lliness: Foundations of a Theory of Personal Conduct (revised edition). New York: Harper \& Row.

Thomason, Sarh Grey, and Terrence Kaufman

1988 Langwage Contact, Creolization, and Genetic Linguistics. Berkeley: University of Califomia Press.
Tillich, Paul

1987 The Essential Tillich: An Anihropology of the Writings of Paul Tillich. Ed. F. Forrester Church. New Yort: Macmillan

Weber, Max

1963 The Sociology of Religion. Trans. Ephraim Fischoff. Boston: Beacon Prest. 